\title{
Sınırlayıcı Odak Parçacığı Sadece’nin Edinimi
}

\author{
Simge Topaloğlu ${ }^{1}$, Mine Nakipoğlu ${ }^{2}$ \\ ${ }^{1,2}$ Boğaziçi Üniversitesi Dilbilim Bölümü, John Freely Hall, 34342 Bebek / İstanbul \\ ${ }^{1}$ simge.topaloglu711@gmail.com, ${ }^{2}$ nakipogl@boun.edu.tr \\ (Gönderilme tarihi 20 Kasım 2016; kabul edilme tarihi 22 Mart 2017)
}

ÖZ: $\mathrm{Bu}$ çalışmada sınırlayıcı odak parçacı̆̆ı sadece'yi içeren tümceleri Türkçe edinen okul öncesi çocukların nasıl yorumladıklarını inceleyerek çocukların tümcelerin odağını belirlemede ne tür sözdizimsel, anlamsal ve/veya edimsel ipuçlarını kullandıklarına 1 şık tutmayı hedeflemekteyiz. Çalışmamız dil edinimi alanyazınında odak parçacıklarının çocuklarca kavranışını Türkçe'de inceleyen ilk çalışma olması açısından önem taşımaktadır ve deney materyallerinin tasarımında Türkçe'nin çalkalama gibi özgün sözdizimsel özelliklerinden de yararlanarak alanyazında daha önce saptanmış hataların çocukların odak parçacıkları için yanlış bir sözdizimsel gösterim kuramlamalarından değil, tümcenin nesnesini veya - çoğu zaman nesneyle örtüştüğü için nesneden kolayca ayrımsanamayan - son ad öbeğini tümcenin odağı kabul etmelerine yol açan edimsel bir yanlılık geliştirmelerinden kaynaklandığı görüşünü savunmaktadır.

Anahtar Sözcükler: Türkçe'nin edinimi, odak, sınırlayıcı odak parçacıkları, edimsel gelişim, doğruluk değeri yargılama testi

\section{The Acquisition of the Turkish Focus Particle Sadece ("Only")}

ABSTRACT: This study aims to investigate what kinds of syntactic, semantic and/or pragmatic cues children use in order to determine the focus of a sentence, by examining how Turkish-acquiring preschoolers interpret sentences that contain the restrictive focus particle sadece ("only"). Our study constitutes the first inquiry into the comprehension of focus particles in Turkish in the acquisition literature, and by utilizing unique syntactic properties of Turkish such as scrambling in designing the experimental materials, it maintains the view that the scope misassignment errors detected in previous studies on languages other than Turkish stem from a pragmatic bias that causes children to designate the object NP or the last NP of the sentence - which often coincides with the object NP - as the default focus, and not from instantiating a non-adult-like syntactic representation for sentences with focus particles.

Keywords: acquisition of Turkish, focus, restrictive focus particles, pragmatic development, truth value judgment task 


\section{Giris}

Sadece, Türkçede etki alanı sözdizimsel olarak k-buyurma (c-command) altında belirlenen, etki alanına aldığı ögeyle bir odak öbeği oluşturan ve tümcenin doğruluk koşullarını sınırlayan bir odak parçacığ ıdır (focus particle). Sadece ve türevi odak parçacıklarının etki alanının k-buyurma türü bir dizilimle belirlendiği görüşü Jackendoff (1972) tarafindan öne sürüldüğünden bu yana anlambilim alanyazınında yaygın olarak kabul görmektedir (Bayer, 1996, s. 16; Büring ve Hartmann, 2001; Rooth, 1985, s. 96). ${ }^{1}$

Söz konusu çalışmalar çoğunlukla İngilizce ve Almanca'daki odak parçacıkları üzerine yapılmış olsa da bu çalışmalarda ortaya konan genellemelerin Türkçe'deki odak parçacıkları için de geçerli olduğunu (1)'de verilen örneklerde görebiliriz.

(1) a. [oö Sadece Ali] satranç oyna-d1.

b. Ali [oö sadece satranç] oyna-di.

(1a) tümcesinde sadece tümcenin öznesi olan 'Ali' ögesine k-buyurmakta ve etki alanına almaktadır, sonuç olarak sadece ve 'Ali' ögeleri tümcenin odak öbeğini oluşturmaktadır. Anlambilim alanyazınında da kabul gördüğü üzere odak öbeği içeren tümcelerin önemli bir özelliği de tümcenin anlamının önvarsayım (presupposition) ve önesürüm (assertion) adı verilen iki bileşene ayrışmasıdır (Geurts ve van der Sandt, 2004; König, 1991, s. 53). Önvarsayım bileșeni koşulsuz olarak doğru kabul edilirken önesürüm bileşeni doğruluk değeri yargılarına açıktır (König, 1991). Dolayısıyla (1a) tümcesi Ali'nin satranç oynadığı varsayımında bulunurken, Ali'den başka kimsenin satranç oynamadığını öne sürmektedir.

Benzer biçimde (1b) tümcesinde sadece tümcenin nesnesi olan 'satranç' ögesine k-buyurmakta ve onunla bir odak öbeği oluşturmaktadır. Bu tümcede

1 K-buyurma kavramı ilk kez Reinhart (1976, s. 32) tarafından kullanılmıș ve Reinhart bu kavramı aşağıdaki şekilde tanımlamıştır. 'Eğer A ve B budakları arasında başatlık (domination) ilişkisi yoksa ve A budağını başatlayan ilk budak aynı zamanda B budağını da başatllyorsa A budağı B budağına k(urucu)-buyurmaktadır.' Jackendoff (1972, s. 250) odak parçacıklarının etki alanının belirlendiği sözdizimsel yapıyı ise 'Eğer only veya just $\mathrm{X}$ budağı tarafindan başatlanıyorsa, $\mathrm{X}$ ve $\mathrm{X}$ 'in başatladığ veya just'ın sağında bulunan tüm budaklar only ve just'ın etki alanındadır.' ifadeleriyle tanımlamıştır. Buradan anlaşılacağı üzere Jackendoff'un tanımındaki 'only'yi başatlayan $\mathrm{X}$ budağının başatladığı budaklar' ifadesi doğrudan k-buyurma alanının tanımını yapmaktadır; dolayısıyla only'nin etki alanının k-buyurma altında belirlendiği sonucu ortaya çıkmaktadır. 
de Ali'nin satranç oynadığı bir önvarsayım iken, ilk tümceden farklı olarak Ali'nin satrançtan başka bir oyun oynamadığı öne sürülmektedir. Bu tümcelerin doğruluk değeri de önesürüm bileşeninin belirttiği yargıya göre belirlenmektedir; (1a) tümcesinin doğruluk değerini belirlemek için gereken bilgi 'Ali' ögesinin karşıt kümesinde yer alabilecek kişilerin satranç oynayıp oynamadığ 1 , (1b) tümcesinin doğruluk değerini belirlemek için gereken bilgi ise Ali'nin başka bir oyun oynayıp oynamadı̆̆ 1 bilgisidir. Yukarıda örneklendiği üzere, sınırlayıcı odak parçacığı sadece, bulunduğu tümcenin doğruluğunu etki alanına aldığı ve odak haline getirdiği ögelerle sınırlamaktadır ve parçacı̆̆ın tümceye kattığı sınırlayıcı anlam tümcenin önesürüm bileşenini oluşturmaktadır (Lambrecht, 1994).

Sadece odak parçacığını içeren tümcelerin doğru bir şekilde yorumlanması için gereken sözdizimsel (sadece'nin k-buyurma altında belirlenen etki alanının saptanması), anlamsal (sadece'nin sınırlayıcı anlamının ve yarattı̆̆ önvarsayım ve önesürüm anlam bileşenlerinin işlenmesi) ve edimsel (konuşma bağlamında sadece'nin odak öbeğine aldığı ögeyle karşıtlık oluşturan ögelerin belirlenmesi) yetiler göz önüne alındığında, okul öncesi çocukların bu tür tümceleri işlemlemekte zorlanabilecekleri ve birtakım öntanımlı/varsayllan yordamlara (default strategy) başvurabilecekleri öngörülebilir. Nitekim Reinhart (2004) da dil edinimi alanında yapılan bazı çalışmaların bulgularından yola çıkarak odak parçacı̆̆ı içeren tümceleri yorumlamanın çocuklar için çok zor olduğunu belirtmiş ve özellikle odak kümesinde bulunan ögenin karşıt kümesini belirlemenin zorluğunun çocukların odak içeren tümceleri yorumlarken yaptıkları hatalarda önemli bir payı olduğu savını ortaya koymuştur. Kuşkusuz edinim sırasında edindikleri dilden bağımsız olarak tüm çocukların benzer edimsel işlemlemeler yapması söz konusudur. Dolayısıyla çocukların belli bir dilde gösterdikleri yorumlama hatalarının başka dillerde de görülmesi olasıdır. Bu çalışmada da amacımız Türkçe edinen çocukların (1)'deki gibi özne-öncesi ve nesne-öncesi sadece içeren tümceleri nasıl yorumladıklarını incelemek, diğer dillerde yapılan çalışmalarla paralellikler olup olmadığını, Türkçe’nin yapısal özelliklerinin söz konusu tümcelerin işlemlenmesinde çocukları ne ölçüde yönlendirdiğini ve Türkçe edinen çocukların bu tür tümcelerin anlamsal çözümlemesinin gerektirdiği biçimde bir odak kümesi ve karşıt küme kurgulayıp kurgulayamadıklarını ortaya çıkarmaktır.

\subsection{Sadece’nin Edinimi Üzerine Diğer Dillerde Yapılan Çalışmalar}

Sadece odak parçacı̆̆ının edinimi şu ana kadar İngilizce (Crain ve diğ., 1994; Kim, 2011; Paterson ve diğ., 2003), Almanca (Höhle ve diğ., 2016; Müller, 2010; Müller ve diğ., 2011a) ve Mandarinde (Notley ve diğ., 2009; Zhou ve Crain, 2009, 2010) incelenmiş ve bu dillerde okul öncesi çocukların sadece 'nin 
özneyi etki alanına aldığı tümceleri nesne-odaklı kabul etme eğilimi içinde olduğu, sadece'nin nesneyi etki alanına aldığı tümcelerin ise sorunsuzca kavrandığı gözlemlenmiştir.

Söz konusu hatalı yorumların neden kaynaklanabileceği sorusuna sözdizimsel, bilişsel ve edimsel gelişimle ilgili üç farklı açıklama getirilmiştir.

1. Çocukların sözdizimsel yetilerinin gelişmemiş olması ve sadece'yi tümcenin tamamına k-buyuran bir tümcesel belirteç olarak çözümlemeleri ve bu nedenle nesnenin de sadece'nin etki alanında olduğunu kabul etmeleri (Notley ve diğ., 2009; Zhou ve Crain, 2009, 2010).

2. Çocukların kısa erimli belleğinin tümcenin odağını ve karşıt kümeleri işlemek için yetersiz olması (Paterson ve diğ., 2003).

3. Çocukların edimsel yetilerinin gelişmemiş olması ve tümcenin son adöbeğini odak kabul etmek (Kim, 2011) veya tümcenin dolaysız nesnesini odak kabul etmek (Müller, 2010; Müller ve diğ., 2011a) gibi öntanımlı yordamlara başvurmaları.

Sadece odak parçacığını içeren tümcelerin okul öncesi çocuklar tarafından nasıl yorumlandığ 1 ilk olarak Crain, $\mathrm{Ni}$ ve Conway (1994) çalışmasında incelenmiştir. Bu çalışmada araştırmacılar özne-öncesi ve eylem-öbeği-öncesi only ('sadece') içeren tümceler kullanmış ve çocuklardan kendilerine gösterilen bir resme göre bu tümcelerin doğru mu yoksa yanlıș mı olduğunu belirtmelerini istemişlerdir. Örneğin, çocuklara bir ördeğin bir balon ve bir bayrak, bir kedinin bir bayrak ve bir kurbağanın bir balon tuttuğu bir resim sunulmuş ve çocuklardan aşağıda verilen iki tümcenin doğruluk değerini verilen resme göre belirlemeleri istenmiştir.

(2) a. Only the cat is holding a flag.

'Sadece kedi bir bayrak tutuyor.'

Beklenen yanıt: YANLIŞ

b. The cat is only holding a flag.

'Kedi sadece bir bayrak tutuyor.'

Beklenen yanıt: DOĞRU

Söz konusu çalışmada deneye katılan çocukların çoğunlukla beklentilerin tersine her iki tümce türünü de doğru kabul ettiği gözlemlenmiştir. Crain ve diğ. (1994) bu gözlemden yola çıkarak çocukların only'nin etki alanının kbuyurma altında belirlendiğini henüz çıkarımlamamış (inference) olduğu ve bu nedenle yetişkinlerden farklı olarak only'nin sözdizimsel yapıdaki konumunu dikkate almayıp gelişigüzel bir yorum yaptıkları sonucuna ulaşmıştır. Ancak çocukların rastgelelik düzeyinin (chance level) üzerinde bir sıklıkla eylem 
öbeğini odak kabul ediyor olması çocukların tümcenin odağını gelişigüzel bir biçimde belirledikleri düşüncesini doğrulamamaktadır. Nitekim, Crain ve ekibi daha sonra benzer yapıların Mandarin edinmekte olan çocuklarca nasıl yorumlandığını araştırmış (Notley ve diğ., 2009; Zhou ve Crain, 2009, 2010) ve çocukların hatalarının özne-öncesi only için yanlış bir sözdizimsel gösterim kuramlamalarından (hypothesis formation) kaynaklandığı savını ortaya atmışlardır. Bu sava göre (3)'te verilen tümcede bulunan özne-öncesi zhiyou ('sadece') odak parçacığının yetişkin dilinde yalnızca özneye k-buyurması gerekirken (Figür 1), okul öncesi çocukların zhiyou'yu tümcenin tamamına kbuyuran bir tümcesel belirteç olarak algıladıkları (Figür 2) ve bu nedenle nesnenin de zhiyou'nun etki alanında olduğunu düşündükleri öne sürülmüştür. Crain ve ekibi tarafından yine Mandarin üzerine yapılan bir çalışmada Notley ve diğ. (2009) çocukların özne-öncesi zhiyou için ilk olarak kuramladıkları yanlış yapıdan yetişkin dilindeki yapıya geçişlerinin ise kim-ne sorularına verilen 'sadece-NP' türü yanıtların bir bütün oluşturduğunun anlaşılmasıyla gerçekleştiğini ileri sürmüşlerdir.

(3) Zhiyou Yuehan chi-le pingguo.

Sadece John ye-GÖR elma

'Sadece John elma yedi.'

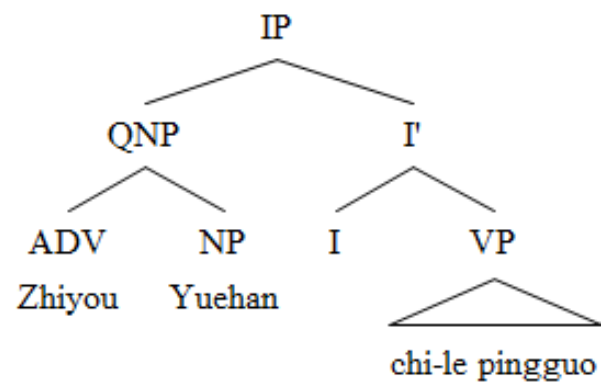

Şekil 1. Yetişkin dilinde tümce (3) 


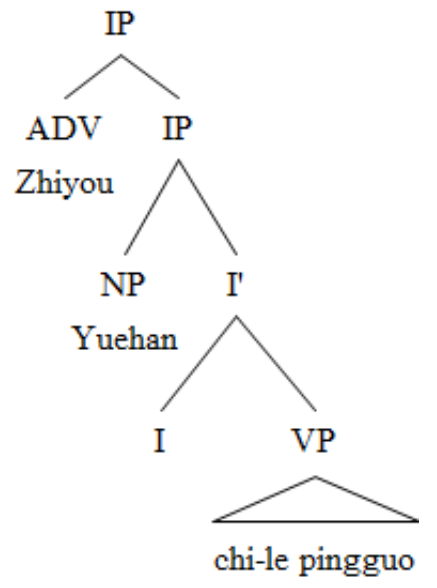

Şekil 2. Çocuk dilinde tümce (3)

Ancak fark edileceği üzere çocukların kuramladığı düşünülen yanlış yapıda da (Şekil 2) zhiyou yalnızca eylem öbeğine değil, aynı zamanda özneye de kbuyurmaktadır. Dolayısıyla Crain ve ekibinin çalışmalarında öne sürülen bu sav çocukların tümceleri nesne-odaklı olarak yorumlama eğilimini açıklamada yetersiz kalmaktadır. Ayrıca söz konusu savda bir döngüsel akıl yürütme hatası bulunduğu da açıktır. Çünkü çocukların yanlış bir sözdizimsel gösterim kuramlıyor olmaları özne-öncesi zhiyou'yu nesneyle ilişkilendirmelerinin nedeni olarak sunulurken, böyle yanlış bir gösterimin çocuk dilinde var olduğuna ilişkin sunulan tek kanıt da özne-öncesi zhiyou'yu nesneyle ilişkilendirme hatalarının varlığıdır. Dolasıyla Crain ve ekibinin çalışmalarında karşılaştığımız bu sav bu yönüyle de hatalıdır. Bu nedenle alanyazında çocukların sadece'nin etki alanını doğru belirleyememelerini çocukların sadece için yanlış bir sözdizimsel gösterim kuramlamalarıyla açıklayan bu savın yanlış varsayımlar üzerinde temellendirildiğini düşünüyoruz.

Sınırlayıcı odak parçacığı içeren tümcelerin çocuklar tarafından nasıl yorumlandığını inceleyen Paterson ve diğ. (2003) ise bu tümcelerin doğru yorumlanmasında kısa-erimli belleğin gelişmişliğinin de önemli bir rol oynayabileceğinin altını çizmiş ve Crain ve ekibinin bulgularını bu etmeni göz önünde bulundurmamaları nedeniyle eleştirmiştir. Paterson ve diğerleri söz konusu deneyde çocukların verilen tümceleri yorumlarken kısa-erimli belleklerinin yetersiz olması nedeniyle only'nin tümceye kattığı sınırlama anlamını çözümlemede ve söylem bağlamında odak kümesinde ve karşıt kümede bulunan ögeleri sınıflandırmada zorlanacaklarını öngörmüştür. $\mathrm{Bu}$ öngörüye uygun olarak da çocukların only'yi tamamen görmezden gelmeleri ve tümceleri bu odak parçacığını içermiyormuşçasına yorumlamaları 
beklenmektedir. Bu beklentinin gerçekleşmesi durumunda ise verilen her iki tümce de ('Sadece kedi bir bayrak tutuyor' ve 'Kedi sadece bir bayrak tutuyor') 'Kedi bir bayrak tutuyor' tümcesiyle eşdeğer tutulacak ve gösterilen resme göre doğru bulunacaktır. Görüldüğü gibi Paterson ve diğ. (2003) tarafından ortaya konan karşı1t açıklama da Crain ve diğ. (1994) deneyinde karşılaşılan yanıt örüntüsünü açıklayabilmektedir.

Paterson ve diğ. (2003) bu varsayımlarını kanıtlamak için ana dili İngilizce olan değişik yaş gruplarından çocukları bir zorunlu resim seçimi deneyinde test etmişlerdir. $\mathrm{Bu}$ deneyde çocuklara 3 farklı tür test tümcesi ve farklı kişilerin farklı nesnelerle etkileşimini gösteren 6 resim verilmiş ve çocuklardan verilen tümcelerin verilen resimlerden hangisi veya hangileri için doğru olduğunu belirtmeleri istenmiştir. Paterson ve diğerlerinin deneylerinde kullandıkları örnek bir test maddesi için kullanılan resimlerdeki karakterlerin hangi nesnelerle etkileştikleri ve resimlere göre doğruluk değeri yargılanacak tümceler aşağıda verilmiştir.

\begin{tabular}{lc}
\hline Resim A: İtfaiyeci $\rightarrow$ hortum & Resim B: Ittfaiyeci $\rightarrow \varnothing$ \\
Polis $\rightarrow \varnothing$ & Polis $\rightarrow$ hortum \\
Resim C: Ittfaiyeci $\rightarrow$ hortum & Resim D: Ittfaiyeci $\rightarrow$ hortum \& merdiven \\
Polis $\rightarrow$ hortum & Polis $\rightarrow \varnothing$ \\
Resim E: Ittfaiyeci $\rightarrow$ hortum \& merdiven & Resim F: İtfaiyeci $\rightarrow \varnothing$ \\
Polis $\rightarrow$ hortum & Polis $\rightarrow \varnothing$ \\
\hline
\end{tabular}

Test tümceleri

a. Only the fireman is holding a hose. (A ve D resimleri için doğru)

'Sadece itfaiyeci bir hortum tutuyor.'

b. The fireman is only holding a hose. (A ve $\mathrm{C}$ resimleri için doğru)

'Itfaiyeci sadece bir hortum tutuyor.'

c. The fireman is holding a hose. (A, C, D ve E resimleri için doğru)

'İtfaiyeci bir hortum tutuyor.'

Çocukların hem only odak parçacığını içeren test tümceleri hem de bu parçacı̆̆ içermeyen kontrol tümceleri için aynı resimleri (A,C,D,E) seçtiğini gözlemleyen Paterson ve ekibi bu sonuçların çocukların only'nin etki alanını belirlemekle ilgili hatalar değil, 'only'-silme hataları yaptıkları varsayımını doğrular nitelikte olduğunu belirtmiştir. Ancak, söz konusu deneyin katılımcılarını her test tümcesini kısa-erimli bellekte tutmaya ve bu tümcenin doğruluk değerini 6 farklı resme göre belirlemeye zorladığı düşünüldüğünde bu deneyin çocuklar için hiç kolay olmadığı söylenebilir. Nitekim 6-7 yaş grubundaki çocuklar test tümcelerinin \%23'ünde, bir diğer deyişle neredeyse her 4 test tümcesinden 1'inde 'diğer' olarak etiketlenen, tanımlanamayan hatalar yapmış, bu hataların only'nin etki alanını belirleme hatası olarak 
sınıflandırılamayacak ve büyük olasıllkla kısa-erimli bellek yetersizliğinden veya dikkatsizlikten kaynaklanan hatalar olabileceği sonucuna varılmıştır. Aynı deneyde kontrol grubu olarak test edilen yetişkinlerin de \%18 oranında 'diğer' türü hatalar yaptıkları göz önünde bulundurulduğunda bu deney tasarımının çok zorlayıcı olduğu ve çocukların odak parçacığı içeren tümceleri kavrayışı hakkında doğru içgörüler sunmuyor olabileceği söylenebilir. Bu deneydeki resimlerin ve test tümcelerinin bir öyküden bağımsız biçimde sunulması ve deneyde bu nedenle sözel bir doku ve bağlam bulunmaması da deneyi zorlaştırdığı gerekçesiyle bazı araştırmacılarca eleştirilmiştir (Müller ve diğ., 2011b).

Konu üzerine yapılan bir başka çalışmada Kim (2011), İngilizce konuşan çocukların çift-geçişli eylemlerle kurulan tümcelerde dolaysız-nesne öncesi only'yi daha önceki deneylerde gözlemlenenin tersine dolaysız nesneyle değil dolaylı nesneyle ilişkilendirdiklerini bulgulamıştır. Örneğin çocuklara 'Toto brought only a book to Mickey Mouse' ('Toto Mickey Mouse'a sadece bir kitap getirdi') gibi bir tümce verildiğinde çocuklar only'yi tümcenin dolaysız nesnesi olan 'a book' ad öbeğiyle değil, dolaylı nesne olan 'Mickey Mouse' ile ilişkilendirme eğilimi göstermişlerdir. Dolaylı nesnelerin aynı zamanda test tümcelerinin son adöbeği olmaları nedeniyle Kim (2011) diğer araştırmacılardan farklı olarak çocukların tümcenin son adöbeğini tümcenin değişmez odağı kabul ettiklerini öne sürmüştür.

Almanca edinen çocukların nur ('sadece') sınırlayıcı odak parçacığını içeren tümceleri nasıl yorumladıklarını araştıran Müller (2010) ise nesnelerin genelde tümcelerin son adöbeği olmasının özne-öncesi nur içeren tümcelerin nesne-odaklı olarak yorumlanmasıyla ilgisi olup olmadığına bakmak için Almancanın çalkalama özelliğinden yararlanarak Nesne-Eylem-Özne öge dizilişine sahip tümceler oluşturmuş ve bu tümcelerde bulunan özne-öncesi nur'un çocuklarca nasıl kavrandığııı incelemiştir. Nesne-Eylem-Özne öge dizilişinin tümcelerin özne-odaklı olarak yorumlanma oranını istatistiksel açıdan anlamlı olacak ölçüde artırmadığını gözlemleyen Müller (2010) nesneodaklı yorum hatalarının tümcenin son adöbeğini odak olarak kabul etme yanlılı̆̆ıyla değil tümcenin nesnesini öntanımlı/varsayılan odak olarak kabul etme yanlılığıyla/eğilimiyle açıklanabileceğini söylemiştir.

Ancak, biz bu deney koşulunda elde edilen sonuçların bu çıkarımı yapmaya olanak sağladığından kuşku duymaktayız. Çocukların son adöbeğini tümcenin odağ 1 kabul edip etmediklerini test etmek için Nesne-Eylem-Özne dizilişine sahip tümceler kullanmak iyi bir fikir olsa da, nesnenin sol çeperde bulunduğu tümceler Almancada çok sık kullanılmamaktadır. Almancada özneyle başlamayan tümcelerde sol çeper ağırlıklı olarak zaman ve yer belirteçleri barındırmaktadır. Örneğin Bohnacker ve Rosén (2008) daha önce yaptıkları bir çalışmada 1990 'l 1 yıllarda derlenmiş ve 25,300 sözcükten oluşan bir gündelik dil bütüncesinde bulunan tümcelerin $\% 52$ 'sinin 
özneyle, \%37'sinin bir belirteçle, \%10'unun nesneyle, ve kalan \%1'inin bu ulamlar dışında kalan bir ögeyle başladığını belirtmektedirler. Bohnacker ve Rosén (2008) aynı makalede sonuçlarını sundukları daha güncel bir çalışmada ise ana dili Almanca olan 70 kişiden kişisel mektuplar, özetler ve kısa öykülerden oluşan 28,500 sözcüklük yazılı bir bütünce derlemişler ve bu derlemde de tümcelerin hangi ögelerle başladığını incelemişlerdir. İlk çalışmanın sonuçlarına benzer biçimde bu derlemdeki tümcelerin \%50'sinin özneyle veya bir dolguyla (expletive), \%17'sinin zaman veya yer belirteçleriyle, \%25'inin zaman ve yer belirteçleri dışında kalan belirteçlerle ve tümcelerin yalnızca \%7'sinin bir nesneyle başladığı gözlemlenmiştir (diğer: \%1). Her iki derlem çalışması da Almancada özneyle başlamayan tümcelerde sol çeperin ağırlıklı olarak belirteçlere ayrılmakta olduğunu, nesneyle başlayan tümcelere ise (her ne kadar bu tür tümceler Almancanın dilbilgisi kurallarına uygun olsa da) çok sık rastlanmadığını göstermektedir. Ayrıca yine Almanca üzerine yapılan başka derlem çalışmaları da NesneEylem-Özne dizilişine sahip tümcelerin kullanıldığı koşullarda nesnenin verili bilgi, öznenin ise yeni bilgi konumunda olması gerektiğini, bunun tersi durumlarda ağırlıklı olarak Özne-Eylem-Nesne öge dizilişine sahip tümceler kullanıldığını göstermiştir (Weber ve Müller, 2004), ancak Müller (2010) ve Müller ve diğ. (2011a) çalışmalarında Nesne-Eylem-Özne dizilişine sahip tümcelerin kullanılmasının uygunluğunu (felicity) sağlayacak (nesneleri 'verili bilgi' olarak sunacak) bir değişimleme yapmamışlardır.

Söz konusu derlem çalışmaları her ne kadar yetişkin dili üzerine yapılmış ve çocuk-yönelimli konuşmada kullanılan tümceleri kapsamıyor olsa da bu çalışmaların bize Almancada tümcelerin öge dizilişlerine göre istatistiksel dağılımı konusunda iyi bir fikir verdiğini söyleyebiliriz. Aynı zamanda, kurallı olmayan tümcelerin çocuk-yönelimli dilde yetişkin diline göre belirgin biçimde daha sık kullanılmasını beklememiz için de bir neden olmadığını düşünmekteyiz. Çocukların kurallı yapıda olmayan tümceleri anlamakta zorlandıklarını ortaya koyan çalışmalar göz önüne alındığında (Dittmar ve diğ., 2008; Grünloh ve diğ., 2011; Sauermann ve Höhle, 2016; Schipke, 2012) çocukların sıklıkla duymadıkları kurallı olmayan bir tümce yapısıyla, üstelik tümcenin en solunda bulunan ögenin Almancada çok sık karşılaşılmayan şekilde 'nesne' olduğu bir yapıyla ve nesnenin 'konu/verili bilgi' olarak sunulmasına dayanak sağlayacak bir söylem bağlamı olmaksızın test edildikleri bir deneyde sağladıkları doğruluk değeri yargılarının ve bu yargılardan çıkarsanan odak yorumlarının güvenilir olduğunun kesin olarak söylenemeyeceğini düşünüyoruz. Üstelik, yetişkinlerin dili işlemleme süresi ve başarısının da tümcelerin sözdizimsel yapısının sıklığından ve/veya tümcelerin içerdikleri bir sözlüksel birimin tümcenin sahip olduğu sözdizimsel yapıyla birlikte kullanılma sıklı̆̆ından etkilendiğini gösteren bulguların varlığında (Hale, 2001; Levy, 2008) çocukları sık duymadıkları 
tümce yapılarıyla test etmenin sorunlu bir yöntem olduğu söylenebilir. Bu nedenle Müller (2010)'da savunulan, çocukların tümcenin son adöbeğini değil, nesnesini odak olarak kabul etme yanlılığı gösterdikleri tezini Türkçe gibi çalkalamaya izin veren ve Nesne-Özne-Eylem dizilişine sahip tümcelerin de daha sık görüldüğü bir dilde test etmenin çocuklarda böyle bir edimsel yanlılık olup olmadığını daha iyi görmemizi sağlayacağını düşünmekteyiz. ${ }^{2}$

$\mathrm{Bu}$ çalışmada da amacımız Türkçe edinen okul öncesi çağındaki çocukların sınırlayıcı odak parçacığı sadece'yi nasıl yorumladıklarını incelemek ve hatalı yorumlarla karşılaşılması durumunda bu hataları alanyazında ortaya konmuş görüşlerden (i. çocukların sadece için yanlış bir sözdizimsel gösterim kuramlaması (Notley ve diğ., 2009; Zhou ve Crain 2009, 2010), ii. çocukların sadece'nin belirlediği odak kümesi için bir karşıt küme oluşturamaması ve sonuç olarak verilen tümceleri sadece yokmuş gibi yorumlamaları (Paterson ve diğ., 2003), iii. çocukların tümcenin son adöbeğini (Kim, 2011) veya tümcenin dolaysız nesnesini öntanımlı odak kabul etmeleri (Müller, 2010; Müller ve diğ., 2011a) ve bunun sonucunda tümceleri yanlış yorumlamaları) hangisinin ya da hangilerinin açıklayabileceğini tartışmaktır. Bu doğrultuda çalışmamızda Türkçe edinen çocukların sadece odak parçacığının kullanımını değerlendirebilecekleri iki ayrı deney tasarlanmış ve farklı yaş gruplarından 100'e yakın çocuk test edilmiştir. Makalemizin ikinci bölümünde bu iki deney tanıtılacak, bulgularımız sunulacaktır.

\section{Sadece’nin Ediniminin Türkçede İncelenmesi}

Türkçe edinen çocukların sadece odak parçacığını içeren tümceleri nasıl yorumladıklarını araştırmak için tasarladığımız ilk deneyde, özne-öncesi ve nesne-öncesi sadece içeren tümcelerin çocuklarca nasıl yorumlandığı, ikinci deneyde ise özne-odaklı tümcelerde çocukların odak yorumlarının verilen sözdizimsel (öge dizilişini değiştirme) ve edimsel (özneleri odak durumuna getiren 'kim-soruları' sorma) ipuçları ile nasıl değiştiği incelenmişstir.

2 Candan ve diğ. (2012) METU-Sabancı Treebank yetişkin dili bütüncesinde (Oflazer ve diğ., 2003) bir adöbeği ile başlayan Türkçe tümcelerin \%52'sinin özne ile \%48'inin ise nesne ile başladığını belirtmektedirler. Bu da Türkçede kurallı tümceler Özne-NesneEylem öge dizilişine sahip olmasına rağmen nesne ile başlayan tümcelerle karşılaşılma olasılığının da neredeyse eşit olduğunu göstermektedir. 


\subsection{Deney 1: Özne-odakll ve Nesne-odaklı Tümceler}

\subsubsection{Katılımcllar}

İlk deneyimiz toplamda 53 çocuğa uygulanmıştır. Test edilen çocuklar yaş gruplarına göre ikiye ayrılmıştır. 1. grupta okul öncesi çağında 33 çocuk (16 kız, 17 erkek; yaş aralığı: 4;01-6;03, yaş ortalaması: 5;04), 2. grupta ilkokul çağında 20 çocuk (10 kız, 10 erkek; yaş aralığı: 6,10-9;09, yaş ortalaması: 8;02) bulunmaktadır. Deney öncesinde çocuklara alıştırma tümceleri verilmiş ve bu tümcelerde gösterdikleri performansa göre deneye devam edip edemeyeceklerine karar verilmiştir. Alıştırma aşamasında hata yapan 8 çocuk (6 okul öncesi, 2 ilkokul) deneye dahil edilmemiştir. Deneye katılan tüm çocuklar İstanbul'da yaşamakta ve okula gitmektedir.

\subsubsection{Yöntem}

$\mathrm{Bu}$ makalede sonuçları bildirilen her iki deneyde de Doğruluk Değeri Yargılama Testi (DDYT) (Truth Value Judgment Task) kullanılmıştır (Crain ve Thornton, 1998). Deneylerde çocuklara bilgisayar ekranında resimler veya resim dizileri gösterilmiş ve bu resimlerle ilgili kısa öyküler anlatılmıştır. Deneyin uygulanmasında her öykünün sonunda ekranda beliren kukla Kermit çocuklara öyküde yaşandığını düşündüğü bir olaydan söz etmekte, ve daha sonra çocuklardan Kermit'in söylediği tümcenin doğru (D) mu yoksa yanlış (Y) mı olduğunu belirtmeleri istenmektedir. Ĕger Kermit'in söylediği tümce doğruysa çocuklar Kermit'in kutusuna ödül olarak bir bilye atmakta, ancak Kermit, tümcesi yanlış olduğunda ödül alamamaktadır.

$\mathrm{Bu}$ deney tasarımının en önemli boyutu çocukların, Kermit'in tümcesinin yanlış olduğunu söylemeleri durumunda bu yanlışın nereden kaynaklandığını açıklamalarının, bir diğer deyişle verdikleri kararı gerekçelendirmelerinin istenmesidir. Verilen yanıtların çözümlemesi de (örneğin yanlış bir yanıtın sadece'nin etki alanının belirlenememesinden mi yoksa başka bir sorundan mı kaynaklandığı sorusunun yanıtlanması) bu gerekçelerden yola çıkılarak yapılmaktadir.

Deneyin uygulanması aşamasında çocuklara test tümceleri verilmeden önce eşleştirildikleri resimlere göre biri (D) diğeri (Y) olan ve odak parçacı̆̆ sadece'yi içermeyen 2 alıştırma tümcesi verilmiş ve çocukların sadece'nin gerektireceği işlemleme becerilerinden bağımsız olarak deneyin gerektirdiği doğruluk değeri yargılama yöntemini daha iyi kavramalarını sağlamak amaçlanmıştır. Alıştırma tümcelerine doğru yanıt veremeyen çocukların deneye devam etmelerine izin verilmemiştir. İlk deneyde toplamda 6 özneodaklı tümce, 6 nesne-odaklı tümce ve 6 dolgu maddesi (filler) kullanılmıştır. Özne-odaklı ve nesne-odaklı tümceler doğruluk değerleri yargilanan tümcelerdir. Dolgu maddeleri ise test tümcelerine eşlik eden resimlere 
benzeyen, ancak herhangi bir tümceyle sunulmayan resimlerden oluşmaktadır ve çocukların bu resimlerde olanları Kermit gibi betimlemeleri istenmektedir. Çocuklar resimleri betimlediklerinde ödül olarak renkli çıkartmalar kazanmaktadırlar. Dolgu maddelerinin deneye eklenme nedenleri arasında deneyin amacını gizlemek, çocukların Kermit'le etkileşim kurma ve deneye devam etme güdülenimlerini artırmak ve deneyde önemli yer tutan doğru yanıtların ödüllendirilmesi yöntemini daha iyi kavramalarını sağlamak sayılabilir.

Doğruluk değeri yargılanan her iki tümce grubunda da (özne-odaklı ve nesne-odaklı) tümcelerin yarısı doğru, yarısı yanlıştır ve tümceler özne-odaklı ve nesne-odaklı yorumlar karşıt doğruluk değerleri verecek biçimde tasarlanmıştır. Tümceler çocuklara karışık sıralamayla verilmiştir. Deneye katılan çocuklar kendi okullarındaki sessiz bir odada test edilmiştir. Bu deneyin tamamlanması yaklaşık 20 dakika sürmektedir.

\subsubsection{Deney Materyalleri ve Öngörüler}

Bu deneyde sınırlayıcı odak parçacı̆̆ sadece 'nin özneyi ve nesneyi etki alanına aldığ1 tümceler kullanılarak Türkçe edinen çocukların bu tümceleri yorumlarken İngilizce, Almanca, Mandarin vb. dilleri edinen yaşıtlarıyla benzer hatalar yapıp yapmadıklarını görmek amaçlanmıştır. Aşağıda bu deneyde kullanılan özne-odaklı (4) ve nesne-odakl1 (5) tümcelere birer örnek verilmiştir. (Deney 1'de kullanılan tüm test maddeleri Ek 1'de listelenmiştir.)

(4) Öykü: Kedi ile fare acıkmışlar ve bir restorana gitmişler. Kedi bir balık ve bir elma yemiş. Fare bir elma yemiş.

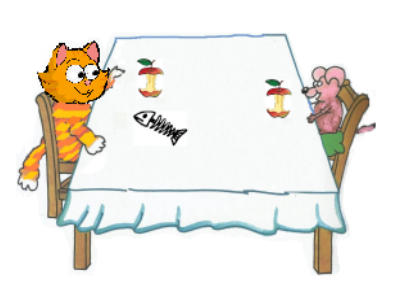

Özne-odaklı test tümcesi: [oöSadece kedi] balık yemiş. Beklenen yanıt: DOĞRU

Nesne-odaklı yorum:

Kedi [oösadece balık] yemiş.

Beklenen yanıt: YANLIŞ 
(5) Öykü: Kedi ile fare ormanda yürüyüşe çıkmışlar ve buldukları ilginç şeyleri toplamışlar. Kedi bir yaprak ve bir kuş tüyü bulmuş. Fare bir kuş tüyü bulmuş.

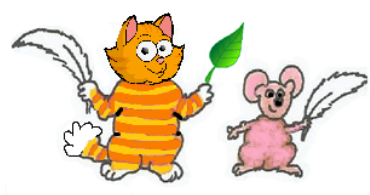

Nesne-odaklı test tümcesi:

Kedi [oösadece yaprak] bulmuş.

Beklenen yanıt: YANLIŞ

Özne-odakl1 yorum:

[oöSadece kedi] yaprak bulmuş.

Beklenen yanıt: DOĞRU

Türkçe edinen çocuklar da özne-öncesi sadece içeren tümceleri (4) alanyazında sadece'nin ediniminin irdelendiği diğer dilleri edinmekte olan yaşıtları gibi nesne-odaklı gibi yorumlama hataları yapıyorlarsa, özne-odaklı tümcelerde doğru tümceleri yanlış, yanlış tümceleri ise doğru kabul ettikleri bir yanıt örüntüsü bulacağımızı öngörüyoruz.

DDYT deneylerinde böyle hatalarla karşılaşılması durumunda hataların sadece'nin etki alanının belirlenememesiyle ilgili olup olmadığını görmek için çocukların verdiği gerekçelerin incelenmesi gerekmektedir. Çocuklar özne-odaklı tümceleri sadece'yi doğru ögeyle ilişkilendiremedikleri için nesne-odaklı olarak yorumluyorlarsa gerekçelerinde söz konusu tümcenin öznesinin etkileştiği diğer nesneden söz etmeleri beklenmektedir. Örneğin yetişkin dilinde verilen resme göre doğru olan 'Sadece kedi balık yemiş' tümcesi çocuk tarafından yanlış olarak değerlendiriliyorsa ve çocuk yanıtını 'Çünkü kedi elma da yemiş’ açıklamasıyla gerekçelendiriyorsa, bir diğer deyişle test tümcesinde verilen öznenin değil, nesnenin karşıt kümesinde yer alan ögeden söz ediyorsa, sadece 'yi açık bir şekilde özne ile değil nesne ile ilişkilendirmektedir. Tümcenin nesnesinin karşıt kümesinde yer alan nesneadayından söz etmeyen gerekçelerin verildiği durumlarda, çocukların hatalarının tümcenin odağını belirlemekle ilgili olmayan bir nedenden (çoğunlukla öykünün doğru anımsanmamasından) kaynaklandığı düşünülmüş ve bu tür hatalar veri çözümlemesi sırasında 'diğer' olarak sınıflandırılmıştır. Paterson ve diğerlerinin (2003) savunduğu gibi bir sadece silme hatası ile karşılaşmamız durumunda ise çocukların tüm tümcelerin doğru olduğunu belirtmeleri gerekmektedir. Çünkü tüm tümcelerin sadece olmaksızın belirttiği önerme (önvarsayım) her zaman doğrudur (örn. 'Sadece kedi balık yemiş’: DOĞRU, 'Kedi sadece yaprak bulmuş': DOĞRU, gibi).

Bunlara ek olarak deneyimize katılan iki farklı yaş grubundan farklı sonuçlar alınacağını öngörmekteyiz. Çocukların tümcenin sözdizimsel, anlamsal ve edimsel özelliklerini kavrama becerilerinin yaş ile gelişeceği göz önüne alındığında ilkokul çağındaki çocukların sadece'yi doğru ögeyle 
ilişkilendirmede okul öncesi çocuklara göre daha başarılı olacakları ve belirgin biçimde daha az hata yapacakları beklenmektedir.

\subsubsection{Bulgular}

Okul öncesi çocukların (Grup 1) ve ilkokul çağındaki çocukların (Grup 2) özne-odaklı ve nesne-odaklı tümceleri nasıl yorumladıkları (özne-odaklı, nesne-odaklı veya diğer) Tablo 1'de gösterilmiştir. Yapılan yorumların tüm yorumların yüzde kaçını oluşturduğu belirtilmiştir; her tümce grubunda bulunan 6 örnekçeden (token) ortalama kaçının özne-odaklı, nesne-odaklı veya 'diğer' olarak etiketlenen bir yorumla okunduğu bilgisi ise yüzde değerlerinin sağında parantez içinde verilmiştir. (örn. Özne-odaklı tümcelerin Grup 1 tarafından \%86.4 oranında nesne odaklı olarak yorumlandığ 1 görülmektedir; bu da 6 özne-odaklı tümceden ortalama 5.18'inin nesne-odaklı gibi algılandığı anlamina gelmektedir.)

Tablo 1. Çocukların özne-odaklı ve nesne-odaklı tümcelerdeki odak yorumları

\begin{tabular}{cllc}
\hline $\begin{array}{l}\text { Özne-odakl1 } \\
\text { Tümceler }\end{array}$ & Özne-odaklı & Nesne-odaklı & Diğer \\
\hline Grup 1 & $\% 8.1(0.48)$ & $\% 86.4(5.18)$ & $\% 5.6(0.34)$ \\
Grup 2 & $\% 60(3.60)$ & $\% 37.5(2.25)$ & $\% 2.5(0.15)$ \\
\hline Nesne-odakl1 & Özne-odakl1 & Nesne-odakl1 & Diğer \\
Tümceler & & & \\
\hline Grup 1 & $\% 1(0.10)$ & $\% 96.5(5.79)$ & $\% 2.5(0.15)$ \\
Grup 2 & $\% 2.5(0.15)$ & $\% 95(5.70)$ & $\% 2.5(0.15)$ \\
\hline
\end{tabular}

Görüldüğü üzere okul öncesi çocuklar özne-odaklı tümceleri \%86.4 oranında nesne-odaklı bir biçimde yorumlamışlardır. Buna karşın bu yaş grubunun doğru yanıt oranı (özne-odaklı yorum) yalnızca \%8.1'de kalmıştır. İlkokul çağındaki çocuklarda ise özne-odaklı tümceler \%60 oranında doğru yorumlanmış, bu tümcelerin nesne-odaklı olarak yorumlanma hatasının \%37.5'e düştüğü saptanmıştır. Ancak tabloda da görüldüğü gibi nesne-odaklı tümcelerde her iki yaş grubu da tümcelerin odağını neredeyse hiç hata yapmadan belirleyebilmiştir. Özne-odaklı ve nesne-odaklı tümce gruplarında bulunan 6'şar örnekçeye verilen ortalama doğru yanıt sayısı üzerinden uygulanan ttestleri ile deneyde hem okul öncesi çocukların (nesne-odaklı tümceler: $O=5.79, \quad S S=0.07$, özne-odaklı tümceler: $O=0.48, S S=0.19 ; t(32)=24.138$, $p<.001$ ) hem de ilkokul çağındaki çocukların (nesne-odaklı tümceler: $O=5.70$, $S S=0.15$, özne-odakl1 tümceler: $O=3.60, S S=0.57 ; t(19)=3.539, p<.01)$ nesneodaklı tümcelerde özne-odaklı tümcelere göre daha başarılı olduğu 
bulgulanmıştır. Ayrıca uygulanan bir Mann-Whitney $U$ testi ile ilkokul çağındaki çocukların $(M d n=4,5)$ okul öncesi çocuklara $(M d n=0)$ kıyasla özneodaklı tümcelerde istatistiksel olarak anlamlı ölçüde daha başarılı oldukları görülmüştür, $U=116, p<.001$. Buna karşın nesne-odaklı tümcelerde okul öncesi çocuklar $(M d n=6)$ ve ilkokul çağındaki çocuklar $(M d n=6)$ arasında anlamlı bir fark görülmemiştir, $U=327, p>.10$.

$\mathrm{Bu}$ sonuçlar bize Türkçe edinen çocukların da sadece'nin ediniminin incelendiği diğer dilleri edinen çocuklar gibi özne-odaklı tümcelerde sadece'yi nesne ile ilişkilendirme hataları yaptıklarını ve bu eğilimin zamanla azaldığını göstermektedir. Peki bu hataların nedeni nedir?

Kermit'in söylediği test tümcelerini reddeden çocukların sundukları gerekçeler bize bir yanıt verebilir. Örneğin pek çok çocuk 'Sadece kedi balık yemiş' tümcesinin yanlış olduğunu belirtmiş ve bu kararı kedinin sadece balık değil, elma da yediğini söyleyerek gerekçelendirmiştir. Bu da bize çocukların bütün tümceleri sadece silme hataları yaparak doğru kabul etmediklerini, tam tersine sadece'nin tümceye sınırlayıcı bir anlam kattığını bildiklerini ve tümcenin odağı olduğunu düşündükleri ögeyi (balık) ve bu odağın karşıt kümesini (elma) belirlemekte zorluk yaşamadıklarını göstermektedir. Tek sorun çocukların tümcenin yanlış bir ögesini odak olarak belirleyip, karşıt kümeyi de bu odağa göre seçmeleridir. Dolayısıyla bu bulgular 1şığında Paterson ve diğerlerinin (2003) öne sürdüğü, çocukların kısa-erimli belleklerinin yetersiz olması nedeniyle odak öbeğini ve karşıt kümeyi belirlemekte zorlandıkları varsayımının kesin olarak yanlışlandığını söyleyebiliriz. Bu bulgulardan yola çıkarak hataların çocukların sözdizimsel yetilerinin mi yoksa edimsel yetilerinin mi gelişmemiş olmasından kaynaklandığını görmek için ise ikinci bir deney tasarladık.

\subsection{Deney 2: Sözdizimsel ve Edimsel Ipuçlarlyla Verilen Özne-odaklı Tümceler}

\subsubsection{Katılımcllar}

İkinci deneyimiz toplamda 43 çocuğa uygulanmıştır. Test edilen çocuklar yaş gruplarına göre ikiye ayrılmıştır. 1. grupta okul öncesi çağında 26 çocuk (13 k1z, 13 erkek; yaş aralığı: 4;04-6;04, yaş ortalaması: 5;03), 2. grupta ilkokul çağında 17 çocuk ( $8 \mathrm{kız}, 9$ erkek; yaş aralığı: 7;05-9;01, yaş ortalaması: 8;06) bulunmaktadır. Deney öncesi çocuklara alıştırma tümceleri verilmiş ve bu tümcelerde gösterdikleri performansa göre deneye devam etmelerine karar verilmiştir. Alıştırma aşamasında hata yapan 9 çocuk (8 okul öncesi, 1 ilkokul) deneye dahil edilmemiştir. Deneye katılan tüm çocuklar İstanbul'da yaşamakta ve okula gitmektedir. 


\subsubsection{Yöntem}

İkinci deneyimizde de birinci deneydeki gibi DDYT kullanılmıştır ve deneyin uygulanışı ilk deneydekiyle aynıdır. Bu deneyde test etmek istediğimiz her iki tümce türünden (edimsel ve sözdizimsel ipuçlarıyla verilen tümceler) 6'şar örnek ve 6 dolgu maddesi bulunmaktadır (toplam 18 test maddesi). Doğruluk değeri yargılanan her iki tümce grubunda da tümcelerin yarısı doğru, yarıs1 yanlıştır ve tümceler özne-odaklı ve nesne-odaklı yorumlar karşıt doğruluk değerleri verecek biçimde tasarlanmıştır. Tümceler çocuklara karışık sıralamayla verilmiştir. Deneye katılan çocuklar kendi okullarındaki sessiz bir odada test edilmiştir. $\mathrm{Bu}$ deneyin tamamlanması yaklaşı 25 dakika sürmektedir.

\subsubsection{Deney Materyalleri ve Öngörüler}

İkinci deneyi tasarlarken çocukların özne-odaklı tümceleri doğru yorumlamakta zorlanmalarının, nesnenin tümce için özneye göre çok daha uygun bir odak olmasından kaynaklanıyor olabileceği varsayımından yola çıktık. Çocukların nesneleri tümcelerin en doğal odağı kabul edip tüm tümceleri öntanımlı bir yordamla nesne-odaklı olarak yorumlamaları için çok iyi bir neden bulunduğunu düşünmekteyiz. Bilindiği üzere verili bilgi-yeni bilgi/konu-odak ayrımı (given-new info/ topic-focus) bilgi yapısının temelini oluşturmaktadır ve dilde verili bilginin tümce ögelerinin çizgisel dizilişinde yeni bilgiden önce geldiği durumlar belirtisiz (unmarked) bir bilgi yapısı oluşturur (Birner ve Ward, 1998, 2009; Chafe, 1970, 1987; Halliday, 1967; Herring ve Paolillo, 1995; Hetzron, 1975; Prince, 1981). Bu nedenle en s1k görülen bilgi yapısında özneler tümcenin konusuyla, nesneler (veya eylem öbekleri) ise odakla örtüşürler (Lambrecht, 1994, 2000). Buna karşın öznelerin odak ve nesnelerin konu konumunda olduğu bilgi yapısı örneklerine daha az rastlanır. Özellikle sadece'nin ediniminin incelendiği dillerin (Türkçe dahil) kurallı öge dizilişlerinde nesnenin özneden sonra geldiği düşünüldüğünde öznekonu/nesne-odak ilişkisinin çocuklar için daha da pekiştiği görülebilir. Dolayısıyla çocukların nesneleri sadece'nin tümce içindeki konumundan bağımsız olarak tümcenin odağı kabul etmeleri çok şaşırtıcı görünmemektedir.

$\mathrm{Bu}$ varsayımı test etmek için ikinci deneyimizde özne-odaklı tümcelerin çocuklar tarafından nasıl yorumlandığını iki farklı değişimleme kullanarak inceledik.

\section{i. Edimsel Değişimleme}

İlk değişimlemede çocuklara birinci deneydeki özne-odaklı tümceler resimleri ve öyküleriyle birlikte sunuldu, ancak ilk deneyden farklı olarak deney gözlemcisi, Kermit öykü hakkında yorum yapmadan önce deneğe 'kim- 
soruları' diyebileceğimiz sorular sordu. ${ }^{3}$ Örneğin (4) numaralı test maddesinde öykünün bitiminde, çocuktan 'Kim elma yemiş?' ve 'Kim balık yemiş?' sorularını yanıtlaması istendi ve Kermit' in test tümcesini söylemesine çocuk bu soruları yanıtladıktan sonra izin verildi. Tümcenin nesnelerinden açıç̧a söz eden ancak özneleri sorgulayan ve onları yeni bilgi/odak haline getiren 'kimsoruları'yla çocukların tümceleri nesne-odaklı olarak yorumlama eğilimi zayıflatılmaya çalışıldı.

Söz konusu değişimlemenin özne-odaklı yorumları kolaylaştırması durumunda ise kuşkusuz çocukların sadece için yetişkinlerden farklı bir sözdizimsel gösterim varsayımında bulunduklarını öne süren açıklamanın doğru olmadığını söyleyebiliriz. $\mathrm{Bu}$ aşamada tümcelerin sözdizimsel yapısında herhangi bir değişiklik yapılmadığı için sözdizimsel açıklamanın çocukların gösterim varsayımının da değişmeyeceğini ve buna bağlı olarak hataların da devam edeceğini öngörmesi gerekir. Ancak tümceler çocuklara verilmeden önce sorulan 'kim-soruları' çocukların tümceleri özne-odaklı olarak yorumlamasını sağlıyorsa, ilk deneyde özne-odaklı okumaları destekleyici bir edimsel ipucunun yokluğunda yapılan nesne-odaklı yorum hatalarının, nesnelerin (veya tümcenin son adöbeğinin) öntanımlı bir yordamla tümcenin odağı kabul edilmesine yol açan edimsel bir yanlılıktan kaynaklandığı düşünülebilir.

\section{ii. Sözdizimsel Değişimleme}

İkinci değişimlemede ise daha önceki deneyde kullanılmamış 6 yeni tümce, çocuklara, Türkçenin çalkalama özelliğinden yararlanılarak Nesne-Özne-Eylem öge dizilişiyle sunuldu. Bu değişimlemeyle amacımız nesneyi tümcenin konusu haline getirirken öznenin eylem öncesi odak alanında kalmasını sağlamaktı (Erguvanlı, 1984). Bu sayede çocukların sadece 'nin özneyi etki alanına aldığ tümceleri özne-odaklı olarak yorumlamaya yatkınlaşacakları öngörüsünde bulunduk. Söz konusu öngörünün gerçekleşmesi durumunda çocukların ilk deneyde gözlemlenen tümceleri nesne-odaklı olarak yorumlama eğiliminin edimsel yetilerinin gelişmemiş olmasından kaynaklandığını söyleyebiliriz. Eğer çocuklar tümcenin son adöbeğini odak kabul ediyorlarsa (Kim 2011) NesneÖzne-Eylem dizilişine sahip tümcelerde özne-odaklı bir yoruma erişebilmeleri beklenebilir. Aynı şekilde eğer çocuklar nesneler çoğunlukla tümcenin odağ oldukları için nesneleri öntanımlı bir yordamla tümcenin odağı olarak kabul ediyorlarsa da (Müller, 2010; Müller ve diğ., 2011a) nesne çalkalama yoluyla sol çepere taşındığı, dolayısıyla 'konulaştırıldığı' ve özne eylem-öncesi odak

3 İkinci deneyin bu koşulunda birinci deneydeki özne-öncesi sadece içeren test tümceleri ve ilgili resimler yeniden kullanıldığı için ilk deneye katılan hiçbir çocuk ikinci deneye alınmamıştır. 
alanında konumlandığı zaman bu eğilimin azalması ve özneyi odak olarak yorumlama eğiliminin artması beklenebilir.

Nesne-Özne-Eylem öge dizilişine sahip test tümcelerinin kullanıldığ 1 bu deney koşulu için ilk deneyde hiç kullanılmamış yeni test maddeleri tasarlanmıştır. Örnek bir test tümcesi ilgili resim dizisi ve kısa öyküsüyle birlikte aşağıda sunulmuştur. ${ }^{4}$ (Bu deneyde kullanılan tüm yeni test maddeleri Ek 2'de verilmiştir.)

(6) Kedi ile kurbağanın bir piyanosu ve bir gitarı varmış. Kurbağa piyanoyu çalmış. Daha sonra kedi piyanoyu çalmış. Ve daha sonra kedi gitarı çalmış.

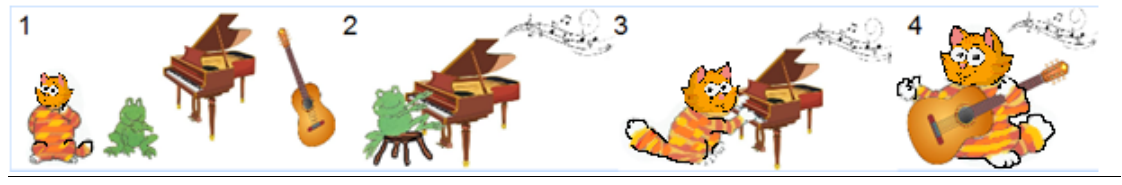

Özne-odaklı test tümcesi: Piyano-yu [oösadece kurbağa] çal-mış.

Beklenen yanıt: YANLIŞ

Nesne-odaklı yorum: Kurbağa [oösadece piyano-yu] çal-mış.

Beklenen yanit: DOĞRU

Yukarıda verilen örnek deney maddesine bakıldığında bu maddede tek bir resim yerine 4 kareden oluşan bir resim dizisi kullanıldığı görülecektir. $\mathrm{Bu}$ resim dizisini ikinci deneyde kullanılan Nesne-Özne-Eylem öge dizilişine sahip olan tümcelerin gerektirdiği gerçekleşme kurallarını (felicity conditions) sağlamak amaciyla tasarladık.

Bilindiği üzere Türkçede nesnenin çalkalama yoluyla eylem-öncesi konumdan ayrılması ve konulaştırılması ancak nesnenin durum eki taşıdığı ve belgili olduğu durumlarda mümkün (örn. *Piyano sadece kurbağa çalmış/ $\checkmark$ Piyanoyu sadece kurbağa çalmış). Nesnenin belgili olabilmesi için ise tanıdık ve özgün olması gerekmekte. Dolayısıyla bu koşulda test tümcelerinin nesnelerinin belgili olmalarını sağlamak için özel resim dizileri tasarladık ve belgili nesnelere gönderim yapılabilmesi için yarattı̆̆ımız resim dizilerine 'arka plan resimleri' (örneğin yukarıdaki dizinin 1. resmi) ekleyerek nesneleri 'tanıdık' hale getirmeyi amaçladık. Öykünün ilk aşamasında çocuklara bu resimler sunuldu ve resimdeki nesneler belgisiz olarak tanıtıldı, böylece öykünün ilerleyen evrelerinde ve sondaki test tümcesinde nesnelerin belgili olabilmesi sağlandı. Ancak belgili bir adöbeğinin kullanılabilmesi için bu

4 Yukarıda da belirtildiği gibi 'kim-soruları' ile sunulan resimler/tümceler ilk deneydekiyle aynıdır. Bu nedenle burada yinelenmelerine gerek duyulmamıştır. 
adöbeğinin tanımladı ̆̆ varlığın tanıdık olması yeterli olmadığı, söz konusu varlığın aynı zamanda 'özgün' olması da gerektiği için 'Piyanoyu sadece kurbağa çalmış’ gibi bir test tümcesinin çocuklara verileceği bir durumda, öyküde - niteliksel olarak birbirlerine özdeş olsalar bile - iki piyano bulunması mümkün değildi. Dolayısıyla görsellerde ve öyküdeki olay örgüsünde her nesneden yalnızca bir örnek bulunması sağlandı. Bunun sonucu olarak da öyküdeki karakterlerin ikisinin de aynı nesneyle etkileşmesi durumunda bu etkileşimlerin ayrı resim karelerinde gerçekleşmesinin daha uygun olacağı düşünüldü (örn. eğer iki karakter, sözgelimi kedi ve kurbağa, piyanoyu çalacaklarsa piyanoyu eşzamanlı olarak değil dönüşümlü olarak çalmalarının daha uygun olması gibi). Dolayısıyla her bir karakterin her bir nesneyle etkileşimi ayrı bir resim karesinde verildi.

Yukarıda da belirttiğimiz gibi bu deneyde, test maddelerine uyguladığımız iki değişimlemenin (i. özneleri söylem bağlamında odak durumuna getirmek amacıyla 'kim-soruları' sorma ve ii. Nesne-Özne-Eylem öge dizilişine sahip tümceler kullanma) özne-odaklı yorum oranlarını ilk deneye kıyasla önemli ölçüde artırmasını beklemekteyiz. $\mathrm{Bu}$ öngörümüzün gerçekleşmesi durumunda ilk deneyde bulgulanan nesne-odaklı yorum hatalarının çocukların geliştirdiği edimsel bir yanlılıktan kaynaklandığını söylemenin mümkün olacağını düşünüyoruz.

\subsubsection{Bulgular}

Okul öncesi çocukların (Grup 1) ve ilkokul çağındaki çocukların (Grup 2) 'kim-soruları' ve Nesne-Özne-Eylem öge dizilişiyle sunulan ve tamamı özneodaklı olan tümceleri nasıl yorumladıkları (özne-odaklı, nesne-odaklı veya diğer) Tablo 2'de gösterilmiştir. Yapılan yorumların tüm yorumların yüzde kaçını oluşturduğu belirtilmiştir; her tümce grubunda bulunan 6 örnekçeden ortalama kaçının özne-odaklı, nesne-odaklı veya 'diğer' olarak etiketlenen bir yorumla okunduğu bilgisi ise yüzde değerlerinin sağında parantez içinde verilmiştir (örn. 'Kim-soruları' ile sunulan tümcelerin Grup 1 tarafından \%67.9 oranında özne-odaklı olarak yorumlandığı görülmektedir; bu da 6 özne-odaklı tümceden ortalama 4.07'sinin özne-odaklı gibi algılandığı anlamına gelmektedir). 
Tablo 2. Çocukların kim-sorularıla ve Nesne-Özne-Eylem dizilişiyle sunulan tümcelerdeki odak yorumları

\begin{tabular}{rccc}
\hline Kim-sorular1 & Özne-odakl1 & Nesne-odakl1 & Diğer \\
\hline Grup 1 & $\% 67.9(4.07)$ & $\% 30.1(1.81)$ & $\% 2(0.12)$ \\
Grup 2 & $\% 93.1(5.59)$ & $\% 6.9(0.41)$ & $\% 0(0.00)$ \\
\hline $\mathrm{N}-$ Ö - E & Özne-odakl1 & Nesne-odakl1 & Diğer \\
\hline Grup 1 & $\% 72.4(4.34)$ & $\% 17.9(1.07)$ & $\% 9.6(0.58)$ \\
Grup 2 & $\% 93.1(5.59)$ & $\% 5.9(0.35)$ & $\% 1(0.06)$ \\
\hline
\end{tabular}

$\mathrm{Bu}$ bulgular bize ikinci deneyde uyguladığımız değişimlemelerin çocukların tümceleri özne-odaklı yorumlama eğilimini belirgin bir biçimde artırdığını göstermektedir. Uygulanan Mann-Whitney $U$ testleri bize okul öncesi çocukların resimlerinde, öykülerinde ve sözdizimsel yapılarında hiçbir değişiklik bulunmayan, yalnızca öncesinde 'kim-soruları' sorulan özne-öncesi sadece tümcelerini özne-odaklı yorumlama oranlarının $(M d n=4)$ ilk deneye göre $(M d n=0) \% 8.1$ 'den \%67.9'a yükseldiğini açıkça göstermiştir, $U=40$, $p<.001$. Benzer şekilde ikinci gruptaki çocukların özne-odaklı yorumlarının oranının da $(M d n=6)$ ilk deneye göre $(M d n=4.5) \% 60$ 'tan \%93.1'e yükseldiği gözlemlenmiştir, $U=94, p<.02$. Bu bulgular da bize test tümcelerini sunmadan önce çocuklara 'Kim elma yedi?', 'Kim balık yedi?' türünde sorular sorarak özneleri söylem bağlamında odak haline getirmenin çocukların özne-odaklı yorumlara erişmelerini sağladığını kanıtlamaktadır.

Daha da önemlisi, bu gelişmenin test tümcelerinde herhangi bir sözdizimsel değişimleme yapılmaksızın elde edilmesi bize çocukların hatalarının sadece'nin yetişkin dilindekinden farklı bir yapısal gösterime sahip olduğunu varsaymalarıyla ilgili olmadığını göstermektedir ve bu yönüyle Crain ve ekibinin çalışmalarında (Notley ve diğ., 2009; Zhou ve Crain, 2009, 2010) karşılaştığımız bu sava karşı kanıt oluşturmaktadır. İlk deneyde de çocukların sadece içeren tümceleri yorumlarken sadece özneyi etki alanına aldığında nesne-odaklı yorum yapmalarına karşın belirledikleri odak kümesine göre bir karşıt küme oluşturabiliyor olmaları da Paterson ve diğerlerinin (2003) çocukların kısa-erimli belleklerinin yetersizliği nedeniyle odak kümesine uygun bir karşıt küme oluşturmakta zorlandıkları savını yanlışlamaktaydı. Bu sonuçlar 1şı̆̆ında ilk deneyde saptanan nesne-odaklı yorum hatalarının kaynağını sözdizimsel ve/veya belleksel değil, edimsel bir yetersizlikte aramak daha doğru olacaktır. Bunu daha ayrıntılı biçimde görmek içinse Nesne-Özne-Eylem dizilişine sahip tümcelerde çocukların nasıl bir performans gösterdiğine bakılmalıdır.

Tablo 2'de görüldüğü üzere nesneyi çalkalama yoluyla konu durumuna getirmek de her iki gruptaki çocukların özne-odaklı yorumlarını artırmıştır. $\mathrm{Bu}$ deney koşulunda okul öncesi çocukların doğru yanıt oranı $(M d n=4)$ ilk 
deneye göre $(M d n=0) \% 8.1$ 'den $\% 72.4$ 'e yükselirken $(U=40, p<.001)$ ilkokul çağındaki çocukların doğru yanıt oranları da $(M d n=6)$ yine ilk deneye göre $(M d n=4.5) \% 60$ 'tan \%93.1'e yükselmiştir $(U=93.5, p<.01)$. Ancak her iki grubun da doğru yanıt oranlarında deneyin her iki koşulunda da istatistiksel olarak anlamlı artışlar gözlemlenmesine rağmen yaş grupları arasındaki fark bu deneyde de sürmüştür. İlkokul çağındaki çocukların doğru yanıt oranları hem 'kim-soruları' sorulan deney koşulunda hem de test tümcelerinin NesneÖzne-Eylem öge dizilişine sahip olduğu koşulda okul öncesi çocukların doğru yanıt oranlarından anlamlı ölçüde daha yüksektir ('kim-soruları': $U=110$, $p<.005$, Nesne-Özne-Eylem: $U=101.5, p<.002$ ).

$\mathrm{Bu}$ deney koşulunda her iki yaş grubunun da özne-odaklı yorumlarında gözlemlediğimiz anlamlı artış bize çocukların ilk deneydeki hatalarının edimsel bir yanlılıktan ileri geldiğini göstermekte. Okul öncesi çocuklar tümcelerin son adöbeğini ögelerin konuların odaklardan önce gelecek biçimde sıralandı̆̆1 bir dizilimin belirtisiz bir bilgi yapısı oluşturması nedeniyle tümcenin en doğal/varsayılan odağ1 olarak kabul ediyor ve buna karşı kanıt oluşturan verileri (örn. nesnenin sadece'nin etki alanında bulunmaması) göz ard1 ediyor olabilirler (Kim, 2011). Bu durumda Nesne-Özne-Eylem dizilişindeki tümcelerde sadece'nin etki alanında bulunmakta olan özne aynı zamanda tümcenin de son adöbeği olduğu için çocukların bu tümceleri özneodaklı olarak yorumlamasının daha kolay olacağı beklenebilir.

Benzer şekilde, eğer çocukların hatalarının nedeni tümcenin son adöbeğini odak kabul etmekten farklı bir edimsel yanlılıksa da (örneğin çocuklar tümcenin nesnelerini nesnelerin odak olduğu durumlar daha s1k görüldüğü ve belirtisiz bir bilgi yapısı oluşturduğu için tümcenin öntanımlı odağı olarak görüyorlarsa) nesneler çalkalama yoluyla 'konu' durumuna getirildiğinde bu edimsel yanlılı̆̆ı baskılanacağını ve sonuç olarak da nesne-odaklı yorumların azalacağını beklemek gerekir (Müller, 2010; Müller ve diğ., 2011a). Nesne-Özne-Eylem dizilişindeki tümcelerde özne-odaklı yorumların oranının istatistiksel olarak anlamlı bir artış göstermesi bu hipotezin öngörüleriyle de uyumludur. İkinci deneyimizde elde ettiğimiz bulgulardan çıkarsayabileceğimiz sonuçları özetleyecek olursak çocukların ilk deneyde gözlemlenen nesne-odaklı yorum hatalarının edimsel bir yanlılıktan kaynaklandığını, ancak bu edimsel yanlılı̆̆a tümcenin son adöbeğinin mi (Kim, 2011) yoksa tümcenin nesnesinin mi doğrudan odak olarak belirlenmesinin (Müller, 2010; Müller ve diğ., 2011a) yol açtığını söylemek için henüz elimizde yeterli kanıt olmadığını ve çift-geçişli eylemleri incelediğimiz, bu çalışmanın devamı niteliğindeki çalışmamızın bu konuya 1ş1k tutacağını düşündüğümüzü söyleyebiliriz. 


\section{Tartıșma ve Sonuc}

$\mathrm{Bu}$ çalışmada İngilizce, Almanca, Mandarin gibi dilleri edinmekte olan okul öncesi çocukların sınırlayıcı odak parçacıkları içeren tümceleri nasıl yorumladıklarını araştırmak için yapılan çalışmalarda elde edilen bulgular ışı̆̆ında Türkçe edinen çocukların odak parçacıklarını nasıl anlamlandırdıklarını ve odak parçacığı içeren tümceleri yorumlamak için gereken anlamsal çözümlemeleri (odak kümesinin ve karşıt kümenin belirlenmesi, verilen bağlama göre önesürüm bileşeninin doğruluk değerinin yargılanması) yapıp yapamadıklarını araştırmayı hedefledik. İlk deneyde elde edilen sonuçlar bize Türkçe edinen çocukların farklı dilleri edinmekte olan yaşıtlarına benzer bir şekilde özne-öncesi sadece içeren tümceleri nesne-odaklı olarak yorumladıklarını gösterdi. Çocukların yanlış olduğunu düşündükleri tümceleri reddettikleri zaman verdikleri gerekçeler sadece odak parçacığının sınırlayıcı anlamını kavramada ve sadece'nin etki alanına aldığını düşündükleri öge için bir karşıt küme bulmakta zorlanmadıklarını ortaya koydu. Bu bulgunun bize nesne-odaklı yorum hatalarının Paterson ve diğerlerinin (2003) savının tersine kısa-erimli bellek yetersizliğinden kaynaklanmadığını göstermesi açısından önemli olduğunu düşünüyoruz.

$\mathrm{Bu}$ çalışmada sunduğumuz ikinci deneyde ise çocukların odak parçacığı içeren tümceleri parçacığın konumundan bağımsız olarak nesne-odaklı olarak yorumlama yanlılığını açıklamak için öne sürülmüş varsayımları test etmeyi hedefledik. Çocuklara sorduğumuz kim-soruları'nın test tümcelerinde sözdizimsel bir değişimleme yapılmamasına karşın doğru özne-odaklı yorumları belirgin biçimde artırması bize çocukların ilk deneydeki nesneodaklı tümce yorumlarının sadece'nin yanlış bir yapısal gösterimi olduğunu varsaymalarından (Notley ve diğ., 2009; Zhou ve Crain 2009, 2010) kaynaklanamayacağına dair kanıt sundu. $\mathrm{Bu}$ da nesne-odaklı yorum hatalarının edimsel bir yanlılıktan kaynaklanıyor olabileceği varsayımını güçlendiren bir bulguydu.

$\mathrm{Bu}$ deneyin ikinci koşulunda ise Türkçenin nesneleri sol çepere taşıyp 'konulaştırmamıza' olanak sağlayan 'çalkalama' özelliğini kullanarak özneler eylem öncesi odak konumunda bulunduğunda çocukların tümceleri özneodaklı olarak yorumlama eğiliminin artıp artmayacağını araştırdık. Beklentilerimiz doğrultusunda deneyde, Nesne-Özne-Eylem öge dizilişine sahip tümcelerde özne-öncesi sadece'nin çocuklar tarafından doğru bir şekilde yorumlandığını ve çocukların özne-odaklı okumalara erişebildiklerini gözlemledik. Bu çalışmada elde ettiğimiz bulguların çocukların odak parçacığı içeren tümceleri nesne-odaklı kabul etmelerini, i. tümcelerin son adöbeklerini öntanımlı odak kabul etmeleriyle (Kim, 2011) veya ii. nesneleri sıklıkla tümcenin odağ 1 oldukları için öntanımlı odak kabul etmeleriyle (Müller, 2010; Müller et al., 2011a) açıklamaya çalışan edimsel hipotezleri desteklediğini düşünmekteyiz. 
Çalışmamızın çocukların dilin anlamsal yapısını çözümlemede ve odak kümesi belirleme/karşıt küme kurgulamada izledikleri yordamları irdeleyerek ve çocukların odak kümesi belirlerken yaptıkları hataların olası edimsel nedenlerini Türkçenin çalkalama gibi özgün dilbilgisel özelliklerinden de yararlanarak anlambilim edinimi alanyazınında tartışılan, çocukların tümceleri nesne-odaklı olarak yorumlama yanlılığının kaynağının ne olduğu sorusuna bir yanıt sunabildiğini umuyoruz. Elde ettiğimiz bulguların söz konusu nesneodaklı yorum yanlılığının, evrensel olduğu kabul edilen konuların odaklardan önce geldiği bir bilgi yapısıyla veya nesnelerin sıklıkla tümcenin odağ1 olmasıyla açıklanabilir olduğunu göstermesinin ise ikinci deneyde yaptığımız değişimlemelerin bu değişimlemelere izin veren başka bir dilde de uygulanması durumunda benzer sonuçlar alınacağı öngörüsünü doğurmasının da önemli bir nokta olduğunu düşünmekteyiz.

Devam eden çalışmalarımızda çocukların sadece 'yi geçişli, geçişsiz, ve çift-geçişli eylemlerle kurulan tümcelerde nasıl yorumladıklarını incelemekteyiz. Özellikle çift-geçişli eylemlerle kurulan tümcelerde, öge dizilişlerini değiştirerek tümcenin son adöbeğinin dolaylı nesne veya dolaysız nesne olabileceği durumlar elde edebildiğimiz için (örn. 'Kedi sadece piyanoyu kurbağaya gösterdi,' 'Kedi piyanoyu sadece kurbağaya gösterdi,' 'Kedi sadece kurbağaya piyanoyu gösterdi,' 'Kedi kurbağaya sadece piyanoyu gösterdi') yeni çalışmalarımızın şu ana kadarki bulgularımızla uyumlu olan iki edimsel hipotezden (i. çocukların tümcenin son adöbeğini öntanımlı odak olarak algılamaları (Kim, 2011), ii. çocukların tümcenin dolaysız nesnesini öntanımlı odak olarak algılamaları (Müller, 2010; Müller ve diğ., 2011a)) hangisinin çocukların hata örüntülerini açıklamada daha iyi olduğunu aydınlatmamızı sağlayacağını umuyoruz.

\section{Kaynaklar}

Bayer, J. (1996). Directionality and Logical Form. Dordrecht: Springer.

Birner, B. J., \& Ward, G. (1998). Information Status and Noncanonical Word Order in English. Amsterdam: John Benjamins.

Birner, B. J., \& Ward, G. (2009). Information structure and syntactic structure. Language and Linguistics Compass, 3(4), 1167-87. http://dx.doi.org/10.1111/j.1749818x.2009.00146.x

Bohnacker, U., Rosén, C. (2008). The clause-initial position in L2 German declaratives: Transfer of information structure. Studies in Second Language Acquisition, 30(4), 511-538. http://dx.doi.org/10.1017/S0272263108080741

Büring, D. \& Hartmann, K. (2001). The Syntax and Semantics of Focus-Sensitive Particles in German. Natural Language and Linguistic Theory, 19, 229-281.

Candan, A., Küntay, A.C., Yeh, Y., Cheung, H., Wagner, L., \& Naigles, L.R. (2012). Language and age effects in children's processing of word order. Cognitive Development, 27(3), 205-221. http://dx.doi.org/10.1016/j.cogdev.2011.12.001 
Chafe, W. (1970). Meaning and the structure of language. Chicago: University of Chicago Press.

Chafe, W. (1987). Cognitive constraints on information flow. In R.S. Tomlin (Ed.), Coherence and Grounding in Discourse, (pp. 21-52). Amsterdam: John Benjamins.

Crain, S., Ni, W.J., \& Conway, L. (1994). Learning, parsing and modularity. In C. Clifton, L. Frazier, \& K. Rayner (Eds.), Perspectives on sentence processing, (pp. 443-467). Hillsdale, NJ: Lawrence Erlbaum.

Crain, S., \& Thornton, R. (1998). Investigations in Universal Grammar: A Guide to Experiments on the Acquisition of Syntax and Semantics. Cambridge, MA: MIT Press.

Dittmar, M., Abbot-Smith, K., Lieven, E., \& Tomasello, M. (2008). German children's comprehension of word order and case marking in causative sentences. Child Development, 79(4), 1152-1167.

http://dx.doi.org/10.1111/j.1467-8624.2008.01181.x

Erguvanl1, E. (1984). The function of word order in Turkish grammar. Berkeley: University of California Press.

Geurts, B. \& van der Sandt, R. (2004). Interpreting focus. Theoretical Linguistics, 30(1), 1-44. http://dx.doi.org/10.1515/thli.2004.005

Grünloh, T., Lieven, E., \& Tomasello, M. (2011). German children use prosody to identify participant roles in transitive sentences. Cognitive Linguistics, 22(2), 393419. http://dx.doi.org/10.1515/cogl.2011.015

Hale, J. (2001). A probabilistic Earley parser as a psycholinguistic model. In Proceedings of NAACL, 2, 159-166.

Halliday, M.A.K. (1967). Notes on Transitivity and Theme in English: Part 2. Journal of Linguistics, 3(2), 199-244. http://www.jstor.org/stable/4174965

Herring, S.C., \& Paolillo, J.C. (1995). Focus position in SOV languages. In P. Downing \& M. Noonan (Eds.), Word Order in Discourse (pp. 163-198). Amsterdam: John Benjamins.

Hetzron, R. (1975). The presentative movement or why the ideal word order is V.S.O.P. In C.N.Li (Ed.), Word Order and Word Order Change (pp. 347-388). Austin: University of Texas Press.

Höhle, B., Fritzsche, T., Müller, A. (2016). Children's Comprehension of Sentences with Focus Particles and the Role of Cognitive Control: An Eye Tracking Study with German-Learning 4-Year-Olds. PLoS ONE 11(3): e0149870. doi:10.1371/journal. pone. 0149870

Jackendoff, R. S. (1972). Semantic Interpretation in Generative Grammar. MIT Press,

Cambridge, Massachusetts.

Kim, S. (2011). Focus particles at syntactic, semantic and pragmatic interfaces: The acquisition of only and even in English. (Yayınlanmamış Doktora Tezi) http://www.ling.hawaii.edu/graduate/Dissertations/SoYoungKimFinal.pdf

König, E. (1991). The Meaning of Focus Particles. London: Routledge.

Lambrecht, K. (1994). Information structure and sentence form. Cambridge: Cambridge University Press.

Lambrecht, K. (2000). When subjects behave like objects: An analysis of the merging of $\mathrm{S}$ and $\mathrm{O}$ in sentence-focus constructions across languages. Studies in Language, 24(3), 611-682. 
http://www.jbe-platform.com/content/journals/10.1075/s1.24.3.06lam

Levy, R. (2008). Expectation-based syntactic comprehension. Cognition, 106(3), 11261177. http://dx.doi.org/10.1016/j.cognition.2007.05.006

Müller, A. (2010). Wie interpretieren Kinder nur? Experimentelle Untersuchungen zum Erwerb von Informationsstruktur. (Yayınlanmamış Doktora Tezi). http://publishup.uni-potsdam.de/opus4-ubp/files/5594/mueller_diss.pdf

Müller, A., Schulz, P. \& Höhle, B. (2011a). How the understanding of focus particles develops: Evidence from child German. In M. Pirvulescu et al. (Eds.), Selected Proceedings of the 4th Conference on Generative Approaches to Language Acquisition North America (GALANA 2010) (pp. 163-171). Somerville, MA: Cascadilla Press.

Müller, A., Schulz, P. \& Höhle, B. (2011b). Pragmatic children: How German children interpret sentences with and without the focus particle only. In J. Meibauer \& M. Steinbach (Eds.), Experimental Pragmatics / Semantics (pp. 79-100). Amsterdam: John Benjamins Publishing Company.

Notley, A., Zhou, P., Crain, S., \& Thornton, R. (2009). Children's Interpretation of Focus Expressions in English and Mandarin. Language Acquisition, 16(4), 240-282. http://dx.doi.org/10.1080/10489220903266669

Oflazer, K., Say, B., Hakkani-Tür, D.Z., \& Tür, G. (2003). Building a Turkish treebank. In A. Abeille (Ed.), Treebanks: Building and Using Parsed Corpora (pp. 261-277). Dordrecht: Kluwer.

Paterson, K. B., Liversedge, S. P., Rowland, C., \& Filik, R. (2003). Children's comprehension of sentences with focus particles. Cognition, 89(3), 263-294. http://dx.doi.org/10.1016/s0010-0277(03)00126-4

Prince, E. F. (1981). Towards a taxonomy of given-new information. In P. Cole (Ed.), Radical Pragmatics (pp. 223-256). New York, NY: Academic Press.

Reinhart, T. (1976). The syntactic domain of anaphora. Dissertation, MIT, Cambridge, Massachusetts.

Reinhart, T. (2004). The Processing Cost of Reference-Set Computation: Acquisition

of Stress Shift and Focus. Language Acquisition, 12(2), 109-155.

Rooth, M. (1985). Association with focus. Dissertation. University of Massachusetts, Amherst.

Sauermann, A. \& Höhle, B. (2016). Impact of Context and Type of Referring Expression on Sentence Comprehension in German-Speaking Children. Proceedings of the 6th Conference on Generative Approaches to Language Acquisition North America (GALANA 2015), ed. Laurel Perkins et al., 90-101. Somerville, MA: Cascadilla Proceedings Project.

Schipke, C. S. (2012). Processing mechanisms of argument structure and case-marking in child development: Neural correlates and behavioral evidence (Unpublished doctoral dissertation). University of Potsdam.

Weber, A., \& Müller, K. (2004). Word order variation in German main clauses: A corpus analysis. Proceedings of the 20th International Conference on Computational Linguistics, Geneva.

Zhou, P., \& Crain, S. (2009). Focus in child language: Evidence from the acquisition of Chinese. In J. Crawford, K. Otaki, \& M. Takahashi (Eds.), Proceedings of the 3rd 
Conference on Generative Approaches to Language Acquisition North America (GALANA 2008) (pp. 336-346). Somerville, MA: Cascadilla Press.

Zhou, P., \& Crain, S. (2010). Focus Identification in Child Mandarin. Journal of Child Language, 37(5), 965-1005. doi: 10.1017/S0305000909990110

\section{EKLER}

EK-1

Özne-odaklı test tümceleri

1) Kısa öykü:

Kedi ve fare acıkmışlar ve bir restorana gitmişler. Kedi bir balık ve bir elma yemiş. Fare bir elma yemiş.

Test tümcesi: [Sadece KEDİ] balık yemiş. DOĞRU

2) Kısa öykü:

Kedi ve fare resim çiziyorlarmış. Kedi bir ev ve bir ağaç çizmiş. Fare bir ev çizmiş. Test tümcesi: [Sadece KEDİ] ağaç çizmiş. DOĞRU

3) Kısa öykü:

Fare ve kurbağa böcek yakalıyorlarmış. Fare bir uğurböceği yakalamış. Kurbağa bir uğurböceği ve bir kelebek yakalamış.

Test tümcesi: [Sadece KURBAĞA] kelebek yakalamış. DOĞRU

4) Kisa öykü:

Kurbağa ve fare ayının doğumgünü partisine gitmişler. Ona yiyecek götürmüşler. Kurbağa bir kek ve bir tavuk pişirmiş, fare bir tavuk pişirmiş.

Test tümcesi: [Sadece FARE] tavuk pişirmiş. YANLIŞ

5) Kısa öykü:

Kurbağa ve tavşan yağmurlu bir günde dışarı çıkıyorlar. Kurbağa bir şemsiye ve yağmur suyu toplamak için bir kova tutuyor. Tavşan bir şemsiye tutuyor.

Test tümcesi: [Sadece TAVŞAN] şemsiye tutuyor. YANLIŞ

6) Kısa öykü:

Kedi ve farenin bahçede bir limon ağaçları ve bir elma ağaçları varmış. Bir gün dışarı çıkıp meyve toplamaya karar vermişler. Kedi elma ve limon toplamış. Fare elma toplamıs.

Test tümcesi: [Sadece FARE] elma toplamış. YANLIŞ

Nesne-odaklı test tümceleri

1) Kısa öykü:

Kurbağa ve tavşan alışverişe gitmişler. Kurbağa bir kazak ve bir pantolon almış. Tavşan bir kazak almış.

Test tümcesi: Tavşan [sadece KAZAK] almış. DOĞRU

2) Kısa öykü:

Kurbağa ve fare bir yarışmaya katılmışlar ve ödül kazanmışlar. Kurbağa bir kitap kazanmış. Fare bir kitap ve bir lolipop kazanmış.

Test tümcesi: Kurbağa [sadece KİTAP] kazanmış. DOĞRU

3) Kısa öykü: 
Kedi ve fare yılbaşı partisindeler. Birbirlerine hediye almışlar, ama hediyeleri henüz açmamışlar. Almak istedikleri hediyeleri düşünüyorlar. Kedi bir tren istiyor. Fare bir tren ve bir araba istiyor.

Test tümcesi: Kedi [sadece TREN] istiyor. DOĞRU

4) Kisa öykü:

Kedi ile fare ormanda yürüyüşe çıkmışlar ve buldukları ilginç şeyleri toplamışlar. Kedi bir yaprak ve bir kuş tüyü bulmuş. Fare bir kuş tüyü bulmuş.

Test tümcesi: Kedi [sadece YAPRAK] bulmuş. YANLIŞ

5) Kısa öykü:

Fare ve kurbağa havuzlarında oyun oynamak istemişler. Oynamak için oyuncaklar getirmişler. Fare bir gemi ve bir top getirmiş. Kurbağa bir top getirmiş.

Test tümcesi: Fare [sadece GEMİ] getirmiş. YANLIŞ

6) Kisa öykü:

Kedi ve fare giysilerini yıkamışlar ve kurutmak için çamaşır ipine asmışlar. Kedi bir tişört ve bir elbise asmış. Fare bir tişört asmış.

Test tümcesi: Kedi [sadece ELBİSE] asmış. YANLIŞ

EK-2

Nesne-Özne-Eylem öge dizilișine sahip özne-odaklı tümceler

1) Kisa öykü:

Kedi ile farenin iki oyuncağı varmış: bir top ve bir ayıcık. Bu oyuncaklarla oynamak istemişler. Önce kedi topla oynamış. Sonra kedi ayıcıkla oynamış. Sonra fare ayıcıkla oynamış.

Test tümcesi: Topla [sadece KEDİ] oynamış. DOĞRU

2) Kısa öykü:

Fare ve kurbağa oyuncakçıya gidiyorlar. Oyuncakçıda bir tren ve bir araba satılıyor. Kurbağa ve fare satın almak istedikleri oyuncaklar hakkında hayal kuruyorlar. Kurbağa treni istiyor. Fare treni ve arabayı istiyor.

Test tümcesi: Arabayı [sadece FARE] istiyor. DOĞRU

3) Kısa öykü:

Fare ve kurbağa hayvanat bahçesine gitmişler ve iki hayvan görmüşler: bir maymun ve bir panda. Fare maymunu beslemiş. Sonra fare pandayı beslemiş. Sonra kurbağa pandayı beslemiş.

Test tümcesi: Maymunu [sadece FARE] beslemiş. DOĞRU

4) Kısa öykü:

Kedi ile kurbağanın bir piyanosu ve bir gitarı varmış. Kurbağa piyanoyu çalmış.

Daha sonra kedi piyanoyu çalmış. Ve daha sonra kedi gitarı çalmış.

Test tümcesi: Piyanoyu [sadece KURBAĞA] çalmış. YANLIŞ

5) Kısa öykü:

Kedi ile tavşan eğlence parkına gitmişler. Eğlence parkında bir dönmedolap bir de atlıkarınca varmış. Kedi ve tavşan dönmedolaba binmişler. Sonra kedi atlıkarıncaya binmiş.

Test tümcesi: Dönmedolaba [sadece TAVŞAN] binmiş. YANLIŞ

6) Kisa öykü: 
Kedi ve fare tiyatroya gitmişler ve çeşitli gösteriler izleyeceklermiş. Sahneye bir balerin çıkmış. Kedi ve fare balerini izlemişler. Fare uyumak için erkenden eve gitmiş. Sonra sahneye bir palyaço çıkmış. Kedi palyaçoyu izlemiş.

Test tümcesi: Balerini [sadece FARE] izlemiş. YANLIŞ 